\title{
Partial trisomy 12q: a clinically recognisable syndrome. Genetic risks associated with translocations of chromosome $12 \mathrm{q}$
}

\author{
N R PRATT* AND D T D BULUGAHAPITIYA $\dagger$ \\ From*the Centre for Human Genetics, Sheffield, and $\dagger$ Rotherham District General Hospital, Rotherham.
}

SUMMARY A newborn child with an unusual facial appearance and multiple abnormalities was found to be trisomic for a large part of $12 \mathrm{q}$ as a result of adjacent 1 segregation of a familial translocation, $\mathrm{t}(9 ; 12)(\mathrm{p} 24 ; \mathrm{q} 21 \cdot 2)$. A combination of cytogenetic analysis, clinical features, and enzyme marker studies allows an accurate assessment of the breakpoints. Although trisomic for a considerably larger area of $12 \mathrm{q}$ than other reported cases, there are many similar features suggesting that trisomy $12 \mathrm{q}$ is a clinically recognisable syndrome. The frequency and mode of segregation of $12 \mathrm{q}$ translocaticins and their implications for genetic counselling are discussed.

\section{Case report}

The proband (fig 1) was the third child of healthy, unrelated parents. Pregnancy and delivery were uneventful, gestation was about 37 weeks, birth weight was $2 \cdot 15 \mathrm{~kg}$, and head circumference was $34 \mathrm{~cm}$. The head was dolichocephalic with frontal bossing and the ears were low set and poorly lobulated. Hypertelorism, macrostomia, and micrognathia were observed, and the bridge of the nose was broad and depressed and the tip turned downReceived for publication 29 July 1982. wards. The neck was short with loose skin and there was a low hairline and excessive body hair. The nipples were wide set. All four extremities showed peripheral cyanosis and there was a valgus deformity of the feet and a dimple at the base of the spine. ECG showed right ventricular hypertrophy. At 14 days hydrocephalus was observed which developed rapidly after 25 days. At 37 days the proband died. Necropsy revealed a gap of abour $5 \mathrm{~mm}$ in the interventricular septum, the lungs were hypoplastic with poor lobe formation, and there was some evidence of brain malformation. Cause of death was

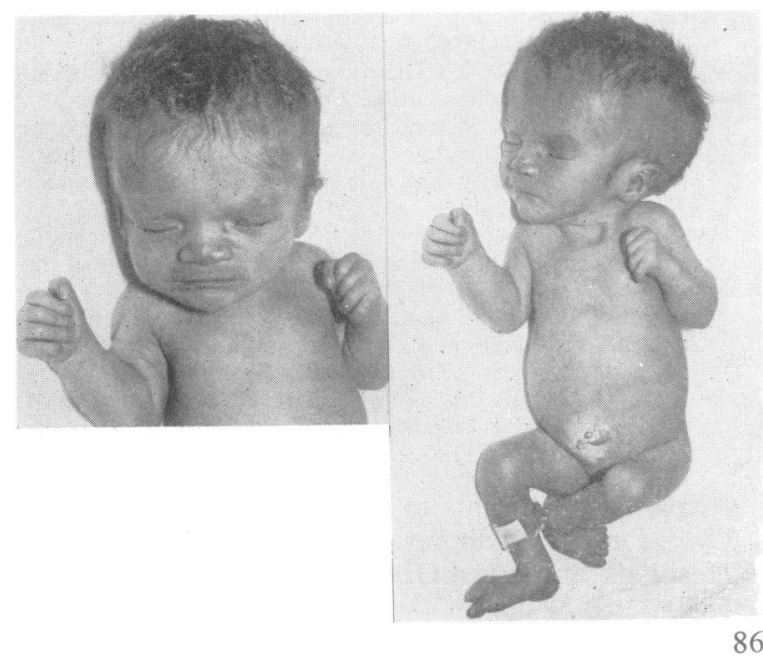

FIG 1 Proband at 12 days. 
thought to be a combination of severe obstructive hydrocephalus and congenital heart defect.

\section{CYTOGENETIC STUDIES}

$\mathrm{G}$ banding of peripheral blood lymphocytes of the proband revealed a $46, \mathrm{XX}$, der(9) karyotype (fig 2B). Analysis of methotrexate treated chromosomes of the proband's parents showed this to be the result of adjacent 1 segregation of a balanced translocation in the mother, 46,XX,t $(9 ; 12)(\mathrm{p} 24 ; \mathrm{q} 21 \cdot 2)$ (fig 2A). The father's karyotype was normal. Further family studies showed the balanced translocation to be present in the mother's father, her brother, and a sister (fig 3).

\section{ENZYME MARKER STUDIES}

The locus of the structural gene for the conversion of galactose-1-phosphate to uridine diphosphate

A

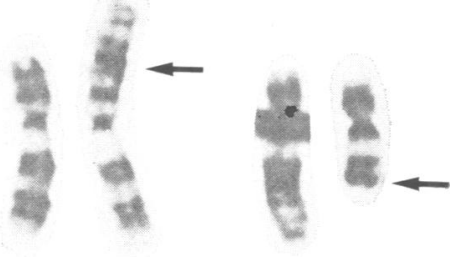

B
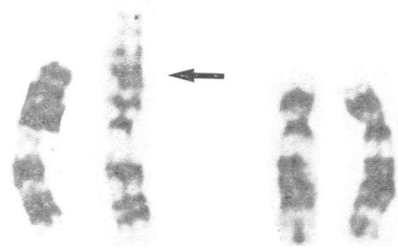

FIG $2 G$ banded partial karyotype of $(A)$ balanced translocation in mother and $(B)$ partial trisomy $12 q$ in proband.

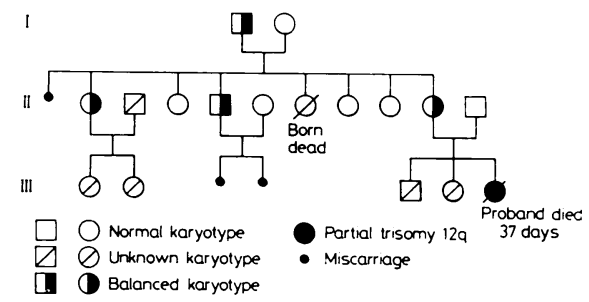

FIG 3 Family pedigree. galactose has been assigned to $9 p$, though the exact position is under dispute. Benn et al ${ }^{1}$ suggested a position of 9 pter $\rightarrow$ p24, but others support a more proximal position. The proband's value of 76 $\mathrm{nmol} / \mathrm{h} / \mathrm{mg}$ protein (normal homozygous range 61 to 100) indicates that the Galt locus is proximal to the breakpoint in the proband. This supports the cytogenetic evidence of the breakpoint of the translocation being very close to 9 pter.

\section{Discussion}

PARTIAL TRISOMY 12q: A CLINICALLY

RECOGNISABLE SYNDROME

As far as we are aware, there are eight reported cases of partial trisomy 12q in newborns (table 1). Six of these have arisen as a result of a familial translocation and two as a result of duplication of $12 \mathrm{q} 24 \rightarrow$ qter. The remarkable similarity between them suggests that trisomy $12 q$ is a clinically recognisable syndrome (table 1).

Trisomy $12 \mathrm{q}$ is characterised by a dysmorphic head, usually dolichocephalic or brachycephalic, which is large relative to length and weight, widely spaced eyes, a flat nasal bridge, down-turned angles of the mouth, low set poorly lobulated ears, a small chin, a short neck with loose skin, a low hairline, widely spaced nipples, a sacral dimple, a simian palmar crease, skeletal abnormalities, cardiopathy, and psychomotor retardation. A sacral dimple has been reported in six cases and a seventh had a hairy patch at the same position. This may be an indication of a neural tube defect. The presence of a sacral dimple in conjunction with the above features could be a useful clinical marker in the diagnosis of future cases of partial trisomy 12q. Five of the above cases had a break at $12 q 24 \cdot 1$ suggesting that there may be a predisposition for breaks at this point. ${ }^{8}$ However, they do not form a subgroup clinically. The three remaining cases had breakpoints at $12 \mathrm{q} 21 \cdot 2$ (present case) and $12 \mathrm{q} 24 \cdot 3 .{ }^{46}$ The similarity of the case of Zabel and Baumann ${ }^{4}$ to the present case suggests that the genes responsible for the clinical features of partial $12 \mathrm{q}$ trisomy are distal to $12 \mathrm{q} 24 \cdot 3$. There has been one further report ${ }^{9}$ of two adult sisters who were trisomic for $12 \mathrm{q} 24 \rightarrow \mathrm{qter}$. They were mentally retarded and had a similar craniofacial dysmorphism. Unfortunately no data were available for the newborn period. The case of Muelenaere et $a l^{9}$ does indicate that there is a possibility of extended postnatal survival for trisomies distal to $12 \mathrm{q} 24$. This is not surprising as only the present case, trisomic for a larger amount of $12 \mathrm{q}$ than the others, showed a lethal developmental defect.

To assess accurately the risk to translocation families of an abnormal child it is necessary to study previously reported cases of $12 \mathrm{q}$ translocations. 
THE FREQUENCY, SEGREGATION, AND RISK ASSOCIATED WITH TRANSLOCATIONS of $12 q$

Until recently cases of partial trisomy $12 q$ have been extremely rare. Roberts $e t a l^{3}$ suggested that this could be the result of a high level of alternate segregation with a low level of inrerstitial chiasma. In the last 3 years, however, there have been five cases of partial trisomy $12 \mathrm{q}$ reported. Furthermore, Ford $e t a l^{8}$ recorded ten cases of unbalanced products out of $1812 q$ translocations. Based on the unusual segregation pattern of $12 q$ translocations we believe that the comparatively low frequency of trisomy $12 \mathrm{q}$ in the newborn population is the result of non-viability of $12 q 13 \rightarrow q 21 \cdot 2$ in an unbalanced form. This is the only region for which there is no liveborn trisomy. Trisomies distal to $12 \mathrm{q} 21 \cdot 2$ resulted from adjacent 1 segregation and had a partial trisomy $12 \mathrm{q}$ phenotype (table 1). Trisomies proximal to $12 \mathrm{q} 13$ resulted from $3: 1$ or adjacent 2 segregation and consequently had a trisomy $12 p$ phenotype (table 2).

Only three of the seven cases in table 2 involve acrocentric chromosomes, suggesting that it is not simply the configuration of the meiotic quadrivalent that has led to $3: 1$ segregation. The absence of adjacent 1 segregation may be the result of nonviability of its products. There are a further 18 reports of balanced translocations involving $12 \mathrm{q} 0 \rightarrow \mathrm{q} 15$ which are not associated with abnormal offspring. ${ }^{81718}$ In these cases and those of table 2 it is clear that there is selection against the products of adjacent 1 segregation. If this were because of nonviability of these products then a history of spontaneous abortion might be expected in affected families. The case of Savary et al $^{14}$ is interesting in this respect. The proband presented with a trisomy $12 p$ phenotype resulting from a postzygotic nondisjunction of a familial translocation (table 2). There were no other abnormal children in the family but in two generations 12 spontaneous abortions out of 31 conceptions occurred; these may well be the result of adjacent 1 segregation products.

Abnormal translocation products of chromosome $12 q$ leading to liveborn offspring occur either from adjacent 1 segregation for breakpoints distal to $12 \mathrm{q} 21 \cdot 2$ or from $3: 1$ segregation for breakpoints proximal to $12 \mathrm{q} 13$. The frequency, however, of

TABLE 1 Cytogenetic and clinical details in cases of partial trisomy $12 q$.

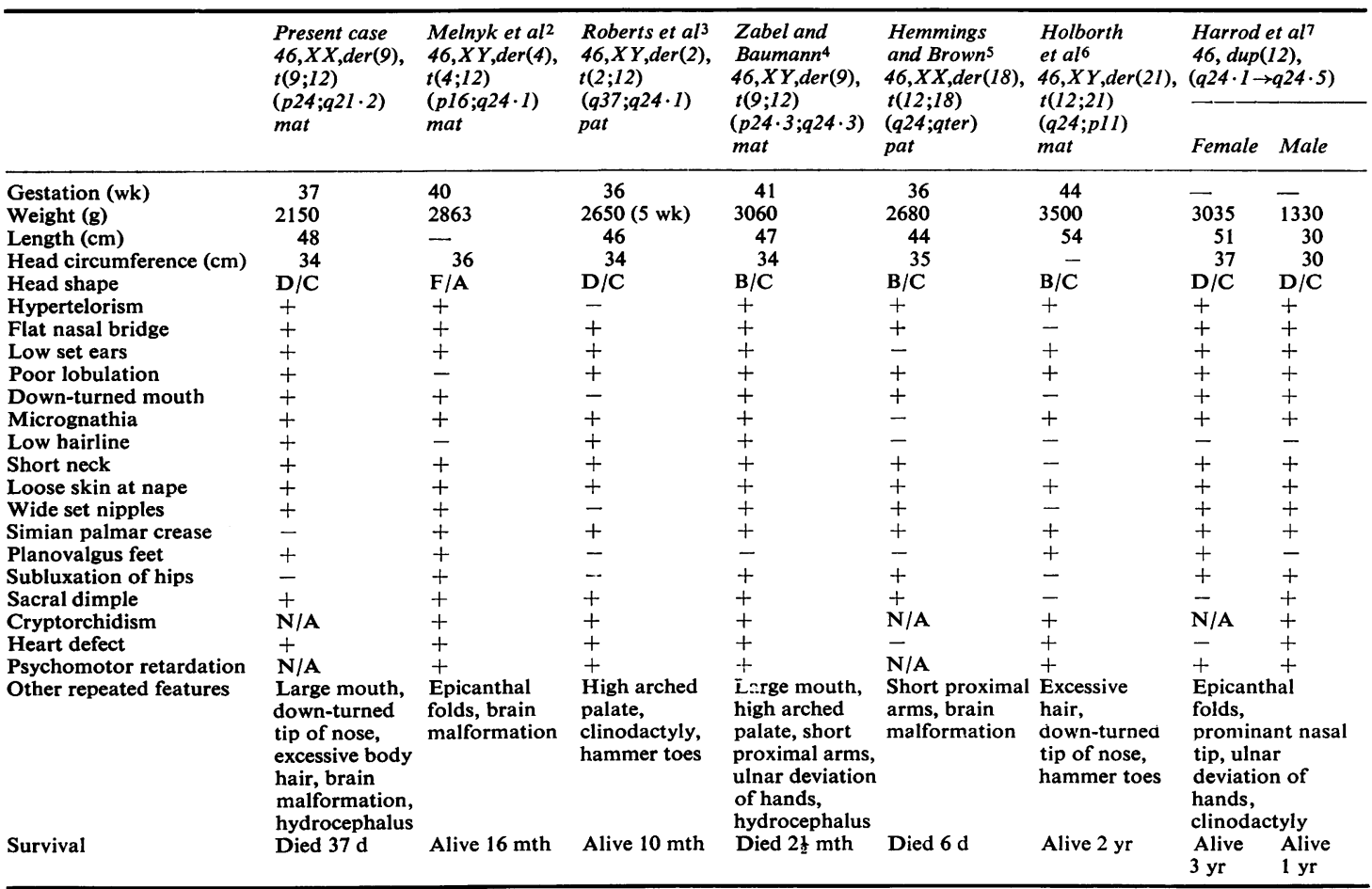

$\mathrm{D} / \mathrm{C}=$ dolichocephalic, $\mathrm{B} / \mathrm{C}=$ brachycephalic, $\mathrm{F} / \mathrm{A}=$ frontal asymmetry, $\mathrm{N} / \mathrm{A}=$ not applicable. 
TABLE 2 Abnormal products of proximal 12q translocations.

\begin{tabular}{|c|c|c|c|c|c|c|}
\hline & $\begin{array}{l}\text { Break on } \\
12 q\end{array}$ & $\begin{array}{l}\text { Break on } \\
\text { other }\end{array}$ & Product & Disjunction & Phenotype & Reference \\
\hline 1 & 11 & $5 \mathrm{p} 14$ & $47, \operatorname{der}(12), \mathrm{t}(5 ; 12)(\mathrm{p} 14 ; \mathrm{q} 11) \mathrm{mat}$ & $3: 1$ & Trisomy $12 p$ & 10 \\
\hline 2 & 12 & $14 \mathrm{p} 11$ & $47, \operatorname{der}(12), \mathrm{t}(12 ; 14)(\mathrm{q} 12 ; \mathrm{p} 11) \mathrm{mat}$ & $3: 1$ & Trisomy $12 p$ & 11 \\
\hline 3 & 12 & $21 \mathrm{q} 11$ & $46,-21, \operatorname{der}(12), \mathrm{t}(12 ; 21)(\mathrm{q} 12 ; \mathrm{q} 11) \mathrm{mat}$ & $2: 2$ & Trisomy $12 \mathrm{p}$ & 12 \\
\hline 4 & 12 & $8 \mathrm{p} 24$ & $47, \operatorname{der}(12), \mathrm{t}(8 ; 12)(\mathrm{p} 24 ; \mathrm{q} 12)$ pat & $3: 1$ & Trisomy $12 \mathrm{p}$ & 13 \\
\hline 5 & 13 & $8 \mathrm{p} 21$ & $47, \operatorname{der}(12), \mathrm{t}(8 ; 12)(\mathrm{p} 21 ; \mathrm{q} 13) \mathrm{mat}$ & Post-zygotic & Trisomy $12 \mathrm{p}$ & 14 \\
\hline 6 & 13 & $5 \mathrm{p} 15$ & $47, \operatorname{der}(12), \mathrm{t}(5 ; 12)(\mathrm{p} 15 ; \mathrm{q} 13) \mathrm{mat}$ & $3: 1$ & Trisomy $12 p$ & 15 \\
\hline 7 & 14 & $21 \mathrm{q} 22$ & $47,+21, \mathrm{t}(12 ; 21)(\mathrm{q} 14 ; \mathrm{q} 22) \mathrm{mat}$ & $3: 1$ & Trisomy 21 & 16 \\
\hline
\end{tabular}

adjacent 1 segregation is far higher than that of $3: 1$ segregation and, therefore, of great importance when assessing risks to translocation families. Balanced translocation carriers whose breakpoints are distal to $12 \mathrm{q} 21 \cdot 2$ are at high risk (greater than 1 in 10) of an abnormal child surviving to term. Translocations whose breakpoints are proximal to $12 \mathrm{q} 13$ are at much lower risk. Stene and StengelRutkowski ${ }^{12}$ calculated that for chromosomes 9,10 , and 12 the risk of unbalanced offspring through $3: 1$ disjunction was about 1 in 50. As there is considerable variation between translocations this figure is likely to be a conservative estimate for most $12 \mathrm{q}$ translocations. By considering the factors affecting 3:1 disjunction, ${ }^{12} 19$ that is, the parental origin of the translocation, the reciprocal chromosome involved, the configuration of the meiotic quadrivalent, and the resultant genetic imbalance, a more accurate assessment of risk can be made.

Balanced translocations of chromosome $12 \mathrm{q}$ may produce either trisomy $12 p$ or trisomy $12 q$ offspring. Both are clinically recognisable syndromes of congenital abnormalities and mental retardation compatible with an extended postnatal survival. The risk of a trisomy $12 p$ infant associated with proximal $12 q$ translocations may be a fraction of that for trisomy $12 \mathrm{q}$ infants from distal $12 \mathrm{q}$ translocations. A similar situation is likely to apply to other translocations and demonstrates the importance of assessing risk with reference to the particular translocation involved. Further studies of existing translocation families will allow increasingly accurate counselling of new reciprocal translocations.

We would like to thank Dr J Holten and Dr A McDermott for the Galt assay.

\footnotetext{
References

1 Benn PA, D'Acona GG, Croce CM, Shows TB, Hellman WJ. Confirmation of the assignment of the gene for galactose-1-phosphate uridyltransferase (E.C.2.7.7.12) to human chromosome 9. Cytogenet Cell Genet 1979;24: $37-42$.

2 Melnyk AR, Weiss L, Van Dyke DL, Jarvi P. Malformation syndrome of duplication 12q24.1 $\rightarrow$ qter. Am J Med Genet $1981 ; 10: 357-65$.

3 Roberts SH, Mattina T, Laurence KM, Sorge G, Pavone L. Partial trisomy $12 \mathrm{q}$ : report of a case and review. $J$ Med Genet $1981 ; 18: 470-3$.
}

4 Zabel B, Baumann W. Partial trisomy 12q. J Med Genett $1981 ; 18: 144-6$.

5 Hemmings L, Brown R. Partial trisomy 12q associated with a familial translocation. Clin Genet 1979;16:25-8.

6 Holborth N, Jacobsen P, Mikkelsen M. Partial trisomy 12 in a mentally retarded boy and translocation $(12 ; 21)$ in his mother. J Med Genet 1974;11:299-303.

7 Harrod MJE, Byrne JB, Dev VG, Francke U. Duplication $12 \mathrm{q}$ mosaicism in two unrelated patients with a similar syndrome. Am J Med Genet 1980; 7 : 123-9.

8 Ford JH, Rofe RH, Pavy RP. Translocations involving chromosome 12. Part I. A report of a 12;21 translocation in a woman with recurrent abortions. Part II. A comparison of the distribution of sites of spontaneous and induced breakages. Hum Genet 1981; 58: 144-8, 279-81.

9 de Muelenaere A, Fryns JP, Van den Berghe H. Partial distal 12q trisomy. Ann Genet (Paris) 1980;23:251-3.

10 Aurias A, Prieur M, Dutrillaux B, Lejeune J. Systematic analysis of 95 reciprocal translocations of autosomes. Hum Genet $1978 ; 45: 259-82$.

11 Rethoré MO, Kaplan JC, Julzen CL, et al. Augmentation de l'activite de la LDH-B chez un garcon trisomique 12p par malsegregation d'une translocation maternelle t $(12 ; 14)$ (q12;p11). Ann Genet (Paris) 1975;18:81-7.

12 Stene J, Stengel-Rutkowski S. Genetic risks for familial reciprocal translocations with special emphasis on those leading to $9 \mathrm{p}, 10 \mathrm{p}$ and $12 \mathrm{p}$ trisomies. Ann Hum Genet $1982 ; 46: 41-74$.

13 Nielsen J, Vetner M, Holm V, Askjaer SA, Reske-Nielsen E. A newborn child with karyotype $47, \mathrm{XX},+\operatorname{der}(12)$ (12pter $\rightarrow 12 \mathrm{q} 12:: 8 \mathrm{q} 24 \rightarrow 8 \mathrm{qter}), \mathrm{t}(8 ; 12)$ (q24;q12)pat. Hum Genet $1977 ; 35: 357-62$.

14 Savary JB, Cousin J, Lai J, Deminett M. Partial trisomy 12 and 8 with mosaicism associated with translocation $\mathrm{t}(8 ; 12)(\mathrm{p} 12 ; \mathrm{q} 13)$. Ann Genet (Paris) 1977;20:122-7.

15 Andre MJ. Etude cytogenetique d'un nouveau cas de trisomie 12p. Nouv Assoc Anat (Nancy) 1976;1970: 455-63.

16 Mikkelsen M. Rare translocation of $47, \mathrm{XY}, \mathrm{t}(12 ; 21)$ Down's syndrome. Hum Hered 1974;24:160-6.

17 Boué A. European collaborative study on structural chromosome anomalies in prenatal diagnosis. In Proceedings of the 3rd European Conference on Prenatal Diagnosis of Genetic Disorders, 1979:34-46.

18 Grace HJ, Laurent C, Serovich FR, et al. Repository of chromosome variants and anomalies in man. Baltimore: Johns Hopkins University Press, 1977.

19 Jalbert P, Sele B, Jalbert H. Reciprocal translocations: a way to predict the mode of inbalanced segregation by pachytene-diagram drawing. Hum Genet 1980;55:209-22.

Requests for reprints to Mr N R Pratt, Centre for Human Genetics, 117 Manchester Road, Sheffield S10 5DN. 